\title{
Fruit removal by hornbills in a semi-evergreen forest of the Indian Eastern Himalaya
}

\author{
Pia Sethi ${ }^{*},+1$ and Henry F. Howe* \\ * Department of Biological Sciences, University of Illinois at Chicago, 845 W. Taylor St. (M/C 066), Chicago, IL 60706, USA \\ $\dagger$ Forestry and Biodiversity Group, The Energy and Resources Institute (TERI), India Habitat Centre, Lodi Road, New Delhi-11003, India \\ (Accepted 5 October 2012)
}

\begin{abstract}
We tested the hypothesis that seed size influences which frugivores eat fruits, and the size and nature of disperser assemblages in Pakke Tiger Reserve, India. Four tree species had large seeds ( $>18 \mathrm{~mm}$ width) that could be handled by birds with large gape widths, while two tree species had smaller seeds ( $<7 \mathrm{~mm}$ width) falling within the gape size range of many frugivores. We tested whether (1) disperser assemblage and activity reflected seed size, and (2) large-gaped hornbills were more effective at fruit removal of tree species with large seeds, than of those with smaller seeds and many dispersers. Day-long watches were conducted in 2005 at trees of Dysoxylum binectariferum (three in 2005 and nine in 2006), Chisocheton cumingianus (nine), Aglaia spectabilis (seven), Polyalthia simiarum (nine), Litsea monopetala (four) and Cinnamomum bejolghota (two in 2005 and six in 2006) to determine which frugivores visited trees and ate fruit. Disperser visitation and species diversity per tree to species with medium-sized seeds averaged 85 visits and 10 species $\mathrm{d}^{-1}$, contrasted with five visits by one frugivore species to large-seeded tree species. Seed

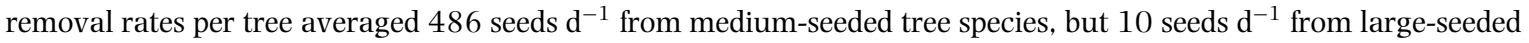
species. Hornbills (Bucerotidae) and Ducula badia (Columbidae) removed large seeds from capsules of Aglaia spectabilis, Chisocheton cumingianus and Dysoxylum binectariferum (Meliaceae). Primates, civets and bats also consumed drupes of large-seeded Polyalthia simiarum (Annonaceae). Anthracoceros albirostris hornbills were important dispersers of Litsea monopetala (Lauraceae), a medium-seeded tree with a large disperser assemblage. Conversely, hornbills were quantitatively inconsequential for Cinnamomum bejolghota (Lauraceae), another medium-seeded tree species with several dispersers. Results suggest that the size and activity of disperser assemblages accurately reflects seed size. While hornbills were quantitatively important dispersers of large-seeded tree species, their effectiveness for trees with smallto medium-sized seeds depended on the tree species.
\end{abstract}

Key Words: Aglaia spectabilis, Chisocheton cumingianus, Cinnamomum bejolghota, Dysoxylum binectariferum, generalist, hunting, Litsea monopetala, Lauraceae, Meliaceae, Polyalthia simiarum, seed-dispersal mutualism, seed size, specialist, tropical rain forest

\section{INTRODUCTION}

Fruit characteristics affect the composition of assemblages of animals that eat tropical fruits and disperse seeds (Jordano 1994, van der Pijl 1982). An ecological reality is that dispersal agents that forage for fruits at a tree species may or may not differ in their effectiveness from the plant perspective. It therefore matters which species of fruiteating animals visit a given tree species, the frequency of those visits, and where they leave seeds (Schupp 1993, Westcott et al. 2005). Because dispersal agents differ in susceptibility to hunting, fragmentation, logging and

\footnotetext{
${ }^{1}$ Corresponding author. Email: sethipia@yahoo.com
}

habitat loss (Corlett 2007, Fa et al. 2005, Hamann \& Curio 1999), the nature of interactions between tree species and intact disperser faunas are important in understanding potential effects of habitat modification and declines of potential dispersal agents from hunting or other disturbances.

Fruit size and nutritional characteristics underpin the 'specialist-generalist paradigm' of plant-frugivore dispersal systems (Howe 1993, McKey 1975). Consistent with the specialist-generalist framework, large seeds together with particularly fat- or protein-rich fruit pulp typify high-investment dispersal syndromes that attract a few loyal frugivore species that consistently disperse seeds to potentially suitable sites for germination and seedling recruitment (Howe 1993). At the generalized 
end of the spectrum, prolific small-seeded tree species represent low-investment strategies for attracting many, generalist frugivores (McKey 1975). The framework may have little relevance to second-growth forests of smallseeded trees with disperser assemblages of small (most $<100 \mathrm{~g}$ ) birds (Carlo et al. 2003). Fruit and seed sizes are important in primary and old secondary tropical forests where trees bearing seeds of large dimensions physically restrict the number of animals that eat large-seeded fruits (Jordano 1995a, Wheelwright 1985). In forests of the Indian Eastern Himalaya, orders of magnitude differences in seed dimensions and in sizes of native fruiteating animals make tests of specialization-generalization feasible.

Here we study seed removal of hornbill-dispersed tree species in forests of the Eastern Himalaya. We compare the seed-removal effectiveness of hornbills and other frugivores for these tree species. Four tree species have extremely large seeds (> $18 \mathrm{~mm}$ width) that can be handled only by birds with wide gapes, while two species have medium-sized seeds $(<7 \mathrm{~mm}$ width) falling well within the gape-size range of many frugivorous birds. We use these tree species to test the following hypotheses: (1) Tree species with small- to medium-sized seeds have many disperser species and higher rates of disperser visitation and seed removal than large-seeded ones because smaller seed size permits birds with both small and large gape widths to eat them. Consequently, disperser assemblage size reflects seed size. (2) Large-seeded tree species depend on large-bodied frugivores with wide gapes, like hornbills and large pigeons, for dispersal, while tree species with small seeds have many dispersal agents. Consequently, large-bodied frugivores are quantitatively effective dispersers of trees with the largest seeds, but are likely to play a lesser role as dispersers of tree species with smaller seeds that attract a diverse disperser assemblage. Here we use visit frequency and number of seeds removed per frugivore (the 'quantitative' dimension of seed-dispersal, Schupp 1993) as approximations of dispersal effectiveness.

\section{METHODS}

\section{Study site}

The study was conducted in Pakke Wildlife Sanctuary $\left(862 \mathrm{~km}^{2}\right)$ located in the East Kameng district $\left(26^{\circ} 54^{\prime} \mathrm{N}-\right.$ $27^{\circ} 16^{\prime} \mathrm{N}, 92^{\circ} 36^{\prime}-93^{\circ} 09^{\prime} \mathrm{E}$ ) of Arunachal Pradesh, India. The forests lie within the Eastern Himalayan biodiversity hotspot (Myers et al. 2000) at the confluence of the Indo-Malayan, Indo-Chinese and Indian biogeographic realms, and have close biological affinities to SouthEast Asia (Mani 1974). The forests of Pakke, part of the northernmost tropical rain forests in the world (Whitmore 1998), have tropical semi-evergreen vegetation (Champion \& Seth 1968). Accessible altitudes are $\sim 200-500 \mathrm{~m}$. Peripheral areas of Pakke sanctuary were commercially logged until the late 1970s, but today logging has ceased and the sanctuary is free of human habitation. Hunting of hornbills in Pakke is negligible due to monitoring by forest staff along with communitycentred initiatives of local conservation agencies. The Reserve Forests surrounding the sanctuary are hunted by tribal communities and affected by tree felling.

\section{Tree species}

Focal tree species include three large-seeded trees with capsular fruits, Dysoxylum binectariferum (Roxb.) Hook.f. ex Bedd., Chisocheton cumingianus (C. DC.) Harms (synonym: C. paniculatus (Roxb.) Hiern) and Aglaia spectabilis (Miq.) Jain \& Bennet (syn.: Amoora wallichii King) (all Meliaceae) and a large-seeded tree bearing drupes, Polyalthia simiarum (Buch.-Ham. ex Hook.f. \& Thomson) Benth. (Annonaceae). Species with smaller seeds are Litsea monopetala (Roxb.) Pers. and Cinnamomum bejolghota (Buch.-Ham.) Sweet (both Lauraceae).

Chisocheton cumingianus and D. binectariferum are medium-sized, evergreen trees bearing dehiscent capsules with arillate seeds. Chisocheton cumingianus fruits from April to July with a peak from mid-May to June (Datta 2001). Black seeds are partially surrounded by orange arillodes. Orange fruits of $D$. binectariferum bear three to four greenish-yellow seeds covered by black arils. Fruiting is from February to May with a peak in March-April (Datta 2001). Aglaia spectabilis is a canopy emergent tree $\sim 40 \mathrm{~m}$ in height bearing dehiscent brown capsules. Fruits contain two or three seeds surrounded by an edible orange aril. Seed size (with aril) averages $29.5 \times 18.8 \times$ $14.7 \mathrm{~mm}$ (Sethi 2010). Fruiting is from May to August peaking in June-July (Datta 2001). Polyalthia simiarum, an evergreen tree $\sim 31 \mathrm{~m}$ in height, bears abundant large drupes that change from green to red when unripe to black when ripe. Most trees fruit from May to August; some also fruit from November to February (Datta 2001, Sethi pers. obs.). Average seed sizes (with aril) of C. cumingianus, $D$. binectariferum and P. simiarum are $31.4 \times 23.7 \times$ $19.3 \mathrm{~mm}, 29.6 \times 22.0 \times 17 \mathrm{~mm}$ and $28.9 \times 19.8 \times$ $17 \mathrm{~mm}$ respectively (Sethi \& Howe 2009).

Litsea monopetala is a dioecious evergreen tree $\sim 15 \mathrm{~m}$ tall. Single-seeded drupes are 7-12 $\mathrm{mm}$ in length and $5 \mathrm{~mm}$ in width (Ara et al. 2007). Fruiting is from June to July. Cinnamomum bejolghota is an evergreen tree with bisexual flowers. The fruit is ovoid, green when young turning blackish green when ripe. The single-seeded drupe averages $10.8 \times 6.5 \times 5.9 \mathrm{~mm}$ (Sethi 2010). Fruiting is in June and July. 


\section{Disperser assemblage}

Large birds feeding at focal trees are hornbills (Bucerotidae) and large fruit pigeons (Columbidae). These include the great Indian hornbill, Buceros bicornis (2.2$3 \mathrm{~kg}$ ), wreathed hornbill, Rhyticeros undulatus (2-2. $5 \mathrm{~kg})$, oriental pied hornbill, Anthracoceros albirostris (0.7$0.8 \mathrm{~kg})$ and mountain imperial pigeon, Ducula badia $(0.5-$ $0.6 \mathrm{~kg}$ ). The green imperial pigeon (D. aenea) also occurs in Pakke but did not visit focal trees in this study. The rufousnecked hornbill (Aceros nipalensis) occurs at elevations > $900 \mathrm{~m}$. Pakke also has a large assemblage of frugivorous or granivorous birds with smaller gape widths, some of which such as the blue-throated barbet (Megalaima asiatica), the lineated barbet ( $M$. lineata) and the hill myna (Gracula religiosa), amongst others fed on the fruits of study trees.

Large-bodied, mammalian frugivores of focal trees include the rhesus macaque (Macaca mulatta) (5-8 kg) in some peripheral areas of the park, and possibly Assamese macaque (M. assamensis). The capped langur (Trachypithecus pileatus) $(\sim 12 \mathrm{~kg})$ also occasionally eats fruits although it is predominantly folivorous (Solanki et al. 2008). Pre-dispersal seed predators include the Malayan giant squirrel (Ratufa bicolor), Pallas redbellied squirrel (Callosciurus erythraeus) and hoarybellied squirrel (C. pygerythrus). Post-dispersal secondary predators include smaller rodents (Velho et al. 2009). Taxonomic nomenclature for birds follows Grimmett et al. (2000), and for mammals follows Menon (2003).

\section{Focal tree watches and visitor assemblages}

Watches of four large-seeded and two medium-seeded tree species were carried out from March to July, 2005 during peak fruit abundance in Pakke (Datta \& Rawat 2003). Watches were conducted at three, nine, seven, nine, four and two trees respectively of Dysoxylum binectariferum, Chisocheton cumingianus, Aglaia spectabilis, Polyalthia simiarum, Litsea monopetala and Cinnamomum bejolghota. To increase sample sizes, we sampled nine additional trees of $D$. binectariferum and six of $C$. bejolghota in 2006. Pooling of data might obscure annual variation in visitation rates to focal trees, but larger samples provide a more accurate estimation of the number and types of dispersers and their relative contribution to seed dispersal (Kitamura et al. 2004). We used the pooled data only to estimate the removal efficiency of frugivores.

Individuals of each species were spaced $>100 \mathrm{~m}$ apart. Each tree was watched from dawn to dusk, approximately 11-12 h. Watches were temporarily halted during heavy rain or intense elephant activity. Because hornbills are wary, camouflaged hides were in place prior to each watch. Hides were occupied before sunrise to minimize disturbance. Crop sizes of medium-seeded species and drupe-bearing large-seeded trees were estimated by counting fruits on five randomly selected branches, averaging the number of fruits and then multiplying this number by the total number of branches on the tree. For species with fewer, easily countable capsules, crop sizes were directly determined with complete fruit counts. These were then multiplied by the average number of seeds per capsule so that crop sizes of all species were in terms of seeds removed.

To determine visitation to trees, we recorded arrival and departure times of each visitor. Vertebrate visitors were identified, categorized by body size, and classified as dispersers (removed seeds from trees), predators (ate or destroyed seeds or moved seeds to arboreal hoards) or non-dispersers (dropped all seeds under parent crowns, pecked at the fruit without dispersing the seeds, or visited the trees but did not feed on fruit or seeds).

\section{Differences of tree species in size and activity of disperser assemblages}

To determine if seed size influences disperser species diversity, abundance, visitation frequency, and visit duration, we grouped tree species into two seed-size classes. For each seed-size class (large and medium) we assessed on a per tree basis differences in: (1) total abundance of dispersers, (2) number of disperser species, (3) number of seeds dispersed (number removed minus the number dropped) and (4) duration of visits. Because fruit crop size influences visitation independently of seed size, we included crop size as a covariate in the analysis. Crop size variation between individuals of a tree species may also influence visitation and seed removal efficiency (Howe \& Vande Kerckhove 1980). We therefore assessed whether crop-size variation amongst individual trees of a particular species influenced visitation rates and/or the number of seeds dispersed per tree.

\section{Removal efficiency of frugivore species}

For individual tree species, we determined the relative effectiveness of each frugivore species in its contribution to seed dispersal. To determine removal efficiency of each frugivore species, we multiplied the mean number of seeds taken per visit by the total number of foraging visits made (Holbrook \& Loiselle 2009). This allows estimates of total number of seeds removed by each consumer during the entire observation period across all trees. These estimates were summed across disperser species to estimate the total number of seeds dispersed. The estimate for each disperser species was divided by this sum to yield the removal efficiency of each disperser, relative to other dispersers. 
For each tree species, we determined if dispersers varied in the number of visits made to each tree and in the number of seeds dispersed per visit. We calculated the number of seeds dispersed per visit by subtracting the number of dropped seeds from the number removed. For purposes of this paper, we consider removed seeds as dispersed.

\section{Statistical analyses}

To determine if seed size influenced visitation in largeand medium-seeded tree species, we assessed differences between these two classes in visitation frequency and seed removal rates using Analysis of Covariance (ANCOVA) with crop size as a covariate and seed size as the independent variable. We included crop size because medium-seeded trees had larger crops $(t=-5.4, \mathrm{df}=30$, $\mathrm{P}<0.001)$. Data were log-transformed prior to analysis to normalize distributions. The influence of variation in crop size between individuals of a particular tree species on visitation rates was also assessed by regressing crop size against (1) number of seeds dispersed per tree and (2) number of disperser visits to each tree.

Differences among disperser species in the quantity of seeds dispersed per visit and number of visits to each tree were assessed for each tree species. We used nonparametric Kruskal-Wallis and Mann-Whitney tests to test whether individual disperser species varied in the number of visits made to each tree or in the number of seeds they removed per visit. Bonferroni corrections for post hoc Mann-Whitney tests were based on the number of follow-up tests conducted. Analyses were performed using SPSS version 15.0.

\section{RESULTS}

\section{Large- and medium-seeded tree classes}

Disperser visitation rates to medium-seeded trees averaged 85 visits per tree per day versus five visits for large-seeded trees (ANCOVA $F_{1,29}=20.8, \mathrm{P}<0.0001$ ) (Figure 1a). Each large-seeded tree was visited on average by one disperser species per day, while each mediumseeded tree was visited by a mean of 10 disperser species $\left(F_{1,29}=22.6, \mathrm{P}<0.0001\right)$ (Figure 1a). Seeds dispersed per tree per day from large-seeded species averaged 10, as compared with 486 for medium-seeded species $\left(F_{1,29}=\right.$ 13.8, $\mathrm{P}<0.002$ ) (Figure 1b). Moreover, large-seeded trees had shorter visit durations per tree (mean $\pm \mathrm{SE}$, $41.9 \pm 8.3 \mathrm{~min})$ than medium-seeded trees $(338 \pm 83.7)$ $\left(F_{1,28}=16.4, \mathrm{P}<0.0001\right)$ (Figure $\left.1 \mathrm{~b}\right)$. Seed size affected rates of visitation and seed removal, but crop size did not. Variation in crop sizes between individuals of a particular tree species also did not influence the number of disperser (a) Mean numbers of disperser visits and disperser species
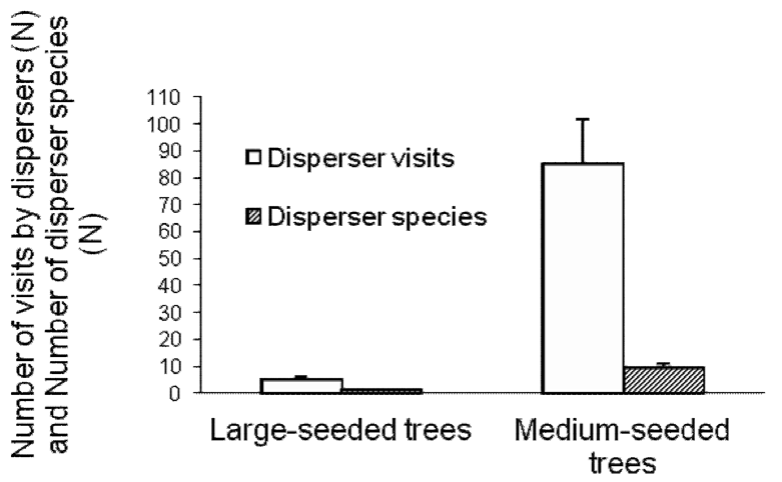

(b) Mean number of seeds dispersed and visit duration

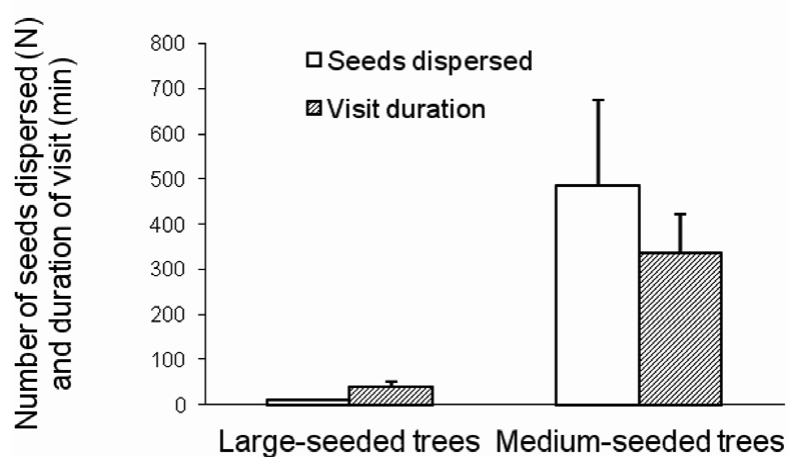

Figure 1. Influence of seed size on the size and activity of disperser assemblages in a semi-evergreen forest of the Indian Eastern Himalaya. Bars represent the number of visits made by dispersers and the number of disperser species (a) and number of seeds dispersed and duration of visits ( $\mathrm{min}$ ) by dispersers (b) per tree per day to large and medium-seeded tree species. Medium-seeded tree species had significantly more disperser species, more visits, more seeds dispersed and longer visit durations by dispersers to trees than did large-seeded ones. Error bars indicate SE.

visits per tree (linear regression, $\mathrm{P}>0.05$ ) or the number of seeds dispersed per tree (linear regression, $\mathrm{P}>0.05$ ) for five of six tree species (A. spectabilis, C. cumingianus, $D$. binectariferum, $P$. simiarum, L. monopetala). The two C. bejolghota trees that were sampled in 2005 precluded analysis of crop size, visits or seeds removed.

\section{Removal efficiency and disperser effectiveness}

Large-seeded, capsular species (A. spectabilis, $C$. cumingianus and $D$. binectariferum) were dispersed by hornbills and Ducula pigeons. Large-seeded, drupaceous P. simiarum (Annonaceae), in contrast, was dispersed by additional animals. Three species of squirrel acted as seed predators, chewing and dropping seeds below parental crowns or moving them away to arboreal caches. Only in rare instances might the few that fell to the ground, sprout. These seeds were considered to be non-dispersed. Details of visitation and seed removal for each tree species 
is provided in Appendix 1. Six species consumed the fruits of $A$. spectabilis, of which three hornbill species and $D$. badia functioned as dispersers. Hornbills were the only avian visitors to $C$. cumingianus trees (25 visits) and removed $32 \%$ of all seeds taken throughout the observation period. Overall $32 \%$ of the seeds were dispersed, the remaining seeds were dropped. Visitation details are in Appendix 1.

Amongst large-seeded capsular trees, $D$. binectariferum had the most seeds dispersed and appeared to be the preferred forage species of hornbills and D. badia. In terms of seeds dispersed per visit, there were significant differences amongst all the four (three hornbill and imperial pigeon) disperser species (Kruskal-Wallis test; $\mathrm{H}=7.9$, $\mathrm{df}=3, \mathrm{P}<0.05)$. Post hoc Mann-Whitney tests found a significant difference between Buceros bicornis ( median $=1, N=38)$ and D. badia $($ median $=2, N=33)$ in the number of seeds dispersed per visit. For the number of visits to each tree, there were no significant differences amongst the four disperser species $(H=2.2$, df $=3$, $\mathrm{P}>0.05)$. Across all sampled trees of $D$. binectariferum, Buceros bicornis was the main disperser, responsible for $36 \%$ of the total dispersal service.

Hornbills visited $P$. simiarum trees more frequently (19 visits) than Macaca mulatta (14 visits) or D. badia (1 visit). Hornbills dispersed $11 \%$ of all the seeds taken and D. badia $0.1 \%$. Tree use by M. mulatta was restricted to removal of seeds from one tree located at the periphery of the forest. This macaque is rarely seen in the forest interior.

The smallest of the three hornbill species, Anthracoceros albirostris, appears to be an important disperser of $L$. monopetala. Although trees are visited by numerous avian frugivores (e.g. bulbuls, mynas and barbets), each of these small frugivores dispersed only a few seeds at a time. In contrast, hornbills removed significantly $(U=401$; $\mathrm{P}<0.001$ ) more seeds per visit (median $=50.5$ seeds, $N=14$ ) than small-bodied birds (median $=3$ seeds, $N=164$ ). Ducula badia also removed more seeds per visit (median $=5$ seeds per visit; $N=15$ ) than did smallbodied birds $(U=853, \mathrm{P}<0.05)$, while hornbills removed more seeds per visit than the imperial pigeon $(U=57.5$, $\mathrm{P}<0.05)$. Anthracoceros albirostris removed the same percentage of seeds as other small birds put together. Macaca mulatta also dispersed a similar proportion of seeds to A. albirostris. However, as with P. simiarum, seeds removed by $M$. mulatta were all from one tree near the forest edge. Because M. mulatta is not found in the forest interior, the actual contribution of this species to dispersal of L. monopetala in the protected area is likely negligible. When we excluded the L. monopetala tree at the park border from analysis, A. albirostris removed most (52.3\%) of the seeds while all the smaller-bodied dispersers together removed 33\%, suggesting that the A. albirostris hornbill is a key disperser of L. monopetala.

Overall, small birds visited all sampled C. bejolghota trees more frequently (385 visits) than hornbills (14 visits).
There were also significant differences in the number of visits paid to each tree by hornbills, Ducula badia, Trachypithecus pileatus and smaller-bodied dispersers (Kruskal-Wallis test; $H=13.5$, df $=3, \mathrm{P}=0.004$ ). Significantly fewer visits $(U=357, \mathrm{P}=0.003)$ were paid to each $C$. bejolghota tree by hornbills (median $=0, N=$ 18 ) than by smaller-bodied birds (median $=2, N=70$ ), while there were no significant differences in the number of visits paid to each tree by small-bodied birds and $T$. pileatus $(U=120, \mathrm{P}>0.0167)$ or Ducula badia $(U=$ 123, P > 0.0167); analyses used a Bonferroni correction against a 0.0167 significance level.

Significant differences existed in the number of seeds removed per visit by hornbills, Ducula badia, T. pileatus and smaller-bodied dispersers (Kruskal-Wallis test; $H=13.2$, $\mathrm{df}=3, \mathrm{P}=0.004)$. Significantly more seeds were removed per visit by hornbills $(U=606, \mathrm{P}=0.011)$ (median $=3$, $N=9$ ) than small-bodied birds (median $=0, N=262$ ) but there were no significant differences in removal rates between $D$. badia and smaller-bodied birds $(U=337, \mathrm{P}>$ 0.025): analyses used a Bonferroni correction against a 0.025 significance level.

In percentage dispersal service, however, hornbills removed a small fraction (5.2\%) of the seeds across all sampled $C$. bejolghota trees. Small-bodied birds removed the overwhelming majority (69.9\%) of seeds. Megalaima asiatica removed the most (17.3\%) followed by Gracula religiosa $(12.1 \%)$ and $M$. lineata $(8 \%)$.

\section{DISCUSSION}

Visitor species assemblages, visitation frequency and seed removal of six tree species from the Indian Eastern Himalaya reflected seed size. As predicted, on a per tree basis the medium-seeded trees had far more visits by dispersers, more disperser species, longer visit durations and higher visit frequency than did large-seeded trees. Surprisingly, the much larger crop sizes of medium-seeded species failed to influence these parameters leaving only seed size among the variables of interest as the reliable predictor of seed removal.

Studies in South-East Asia (Becker \& Wong 1985, Kitamura et al. 2004) indicate that large seeds are dispersed by small disperser assemblages. These often consist of hornbills and the imperial pigeon, which are consistent with our results obtained from forests in the north-east of India. In Pakke, hornbills disperse the seeds of over 80 plant species (Datta 2001), but likely are far more effective for some than others. At Pakke, B. bicornis, $R$. undulatus, $A$. albirostris and $D$. badia removed the seeds of Aglaia spectabilis. The same four species along with the brown hornbill (Anorrhinus austeni) fed on fruits of this tree in Khao Yai, Thailand (Kitamura et al. 2004). Both A. spectabilis in Thailand (Kitamura et al. 2004) and 
another Aglaia sp. in Pasoh Forest Reserve in Peninsular Malaysia (Becker \& Wong 1985) depend on hornbills as their primary dispersers. Overall, both our results and the findings from South East Asia suggest that several species of Meliaceae are highly specialized for dispersal by hornbills.

Other vertebrates are unlikely to be important dispersers of large-seed capsular fruits of Meliaceae at Pakke. Capsular fruits of large-seeded Meliaceae do not fit the dull green-yellow or red-brown colour syndrome of fruits dispersed by bats in the Palaeotropics (Hodgkison et al. 2003). Further, no evidence of high fruit consumption at night is found in Thailand for Aglaia spectabilis (Kitamura et al. 2004). There is little evidence to suggest that civets eat the seeds of large-seeded Meliaceae (Sethi, pers. obs.). We doubt that night-time visitors are important foragers on fruits of these capsular species. Arboreal squirrels are unlikely seed dispersers (Becker \& Wong 1985, Leighton \& Leighton 1983). Ratufa bicolor, Callosciurus erythraeus and C. pygerythrus are pre-dispersal seed predators, chewing and biting capsules and seeds and dropping them to the forest floor.

The study might underestimate assemblage sizes of dispersers. We did not examine secondary seed removal/predation on the forest floor. However, while high levels of rodent predation have been observed on some Meliaceae species such as D. binectariferum, scatter hoarding is rare; one estimate suggested that only $1.4 \%$ of the seeds of five tree species were cached at Pakke (Velho et al. 2009). In Thailand (Kitamura et al. 2002), as in our study, mammals other than rodents avoid the dehiscent fruits of the Meliaceae. This is probably because limonoids, a group of distasteful oxidized triterpenes, are widespread in the Meliaceae (Pannell \& Koziol 1987), and have been extracted from C. cumingianus seeds (Connolly et al. 1979, Saikia et al. 1978). Squirrels, which feed extensively on Meliaceae seeds, unlike other mammals, appear to have evolved ways (Pannell \& Koziol 1987) to tolerate these plant chemical defences.

Large-seed-bearing trees like $P$. simiarum (Annonaceae) may attract more dispersers than those belonging to large-seeded Meliaceae. This is because P. simiarum has multiple fruiting seasons, large crop sizes and easyto-handle drupaceous fruits. At Pakke, eight frugivores fed on the fruits of $P$. simiarum, and five species dispersed them. The study did not take into account nocturnal visitors to the canopy such as bats or civets, but other studies suggest that bats disperse the fruits of several Polyalthia species, including P. simiarum (Elangovan et al. 1999, Hodgkison et al. 2003, Kashmira Kakati pers. comm.). We also observed P. simiarum seeds in civet scats. Moreover, while secondary dispersal of the Meliaceae appears unlikely, we cannot discount subsequent dispersal of $P$. simiarum or of the medium- seeded trees. Nevertheless, the disperser assemblage size of $P$. simiarum is much smaller than the tree species with medium-sized seeds, indicating that the relationship of large seed size with few dispersers is generally applicable to our study area.

Three of the four large-seeded tree species sampled in this study belong to a single family, Meliaceae, while the two medium-seeded species belong to Lauraceae. This suggests that perhaps phylogeny rather than seed size may be responsible for our observed patterns. Globally, however, community-level studies corroborate the role of morphological constraints in limiting disperser assemblages of trees bearing large-seeded crops (Fleming 2005, Gautier-Hion et al. 1985, Hamann \& Curio 1999, Kitamura et al. 2002, Pratt \& Stiles 1985). While other factors such as nutritional qualities may influence disperser assemblage size, seed size explains most variation in frugivore use elsewhere (Wheelwright 1985), and probably does here too. After accounting for shared ancestry, Jordano (1995b) found fruit diameter to be the strongest determinant of disperser type in a sample of fruit traits of 910 angiosperm species.

Hornbills may play a substantial role in the dispersal of some medium-seeded trees with several dispersers. One hornbill species removed significantly more L. monopetala seeds per visit than did a bevy of smaller-bodied birds. Further, when we discounted the tree on the park periphery which was visited by M. mulatta, hornbills, especially A. albirostris, dispersed more than $50 \%$ of the seeds. The pooled assemblage of small birds together dispersed just above 30\%. Hornbills concentrate their foraging during and close to the breeding season on highquality, lipid-rich fruits, particularly the large-seeded study species. Afterwards, during periods of fruit scarcity, they forage more opportunistically on small- to mediumsized fruits (Datta \& Rawat 2003). The smaller-bodied, $A$. albirostris, which preferentially eats smaller fruits than $B$. bicornis or R. undulatus (Datta \& Rawat 2003), is likely an important disperser of $L$. monopetala seeds.

Hornbills may not be important dispersers of $C$. bejolghota. On a per visit basis, hornbills removed more seeds than small birds. However, small birds visited each tree of $C$. bejolghota far more frequently than did hornbills, and together removed most of the seeds across all members of this species sampled. Frequent animal mutualists might contribute the most to seed dispersal even if they are not very effective in the number of seeds dispersed per visit (Vazquez et al. 2005), an effect most relevant to seeds of small or medium size that do not physically restrict ingestion. For C. bejolghota, which does not exclude smaller fruit-eating animals with seeds too large to handle, hornbills appear to be quantitatively trivial dispersers, while smaller Gracula religiosa and barbets were quantitatively more important. However, no species contributed significantly to seed dispersal; each of 
the frugivores dispersed less than $25 \%$ of the seeds. An intriguing thought is that if hornbills were to increase their visitation rates to this species for whatever reason (e.g. preferred species logged out), the situation could alter due to the much greater seed-carrying capacity of the larger birds.

In all the large-seeded and one of the medium-seeded tree species, most disperser species accounted for less than $25 \%$ of the dispersal services the tree received. This suggests that only a few disperser species remove most of the seeds of a given tree species, consistent with the results reported by Schupp et al. (2010). A general pattern of dependence on one or few disperser species has implications for the resilience of dispersal systems, especially by large-bodied frugivores that are particularly vulnerable to habitat loss, fragmentation and hunting.

Qualitative aspects are critical to determining the overall success of a dispersal event. For example, some dispersers that remove relatively few fruits can have a disproportionate effect on plant recruitment, e.g. by providing long-distance dispersal (Jordano et al. 2007) or directed dispersal (Wenny \& Levey 1998). Unfortunately, we were not able to assess the qualitative aspects of disperser effectiveness. Nevertheless, our study throws light on the quantitative dimension of dispersal in an understudied part of the world, clearly indicating that few dispersers are responsible for more than $25 \%$ of the dispersal services provided to a tree species.

Our results suggest that the relationship of largebodied dispersers to trees whose fruits are eaten by many dispersers is contingent. Large dispersal agents may be quantitatively important during some seasons for some tree species, but of our sample of two tree species with medium-sized seeds, A. albirostris was important for one tree species but hornbills had rather little effect on seed dispersal of the other.

Dispersal effectiveness is relevant to the conservation of tropical forests disturbed by human activity. Seedsize might predict the sensitivity of tree guilds to habitat alteration and disperser loss (Cramer et al. 2007, NunezIturri et al. 2008, Sethi \& Howe 2009). In the Indian Eastern Himalaya, determining which guilds of hornbilldispersed trees actually depend on hornbills and which are effectively dispersed by other animals is crucial where hornbill numbers are fast dwindling. Of the 80 tree species dispersed by hornbills at our site, many include seeds of small to medium size; it is not clear how many of these trees are actually threatened by declining hornbill populations increasingly decimated by logging and hunting. Throughout the tropics, rational management of forests will require identification of the extent to which different dispersal agents are critical to or incidental for the natural regeneration of trees with animal-dispersed seeds.

\section{ACKNOWLEDGEMENTS}

The first author thanks the Arunachal Pradesh Forest Department for providing permits. Chuka Loma, Pekyom Ringu and Tana Tapi facilitated this research in innumerable ways. Tejaram, Devar Tachung and Gautam Nath provided invaluable help in the field. Anupam Sarmah identified plant specimens and Aparajita Datta and Kashmira Kakati provided important information. Norbert Cordeiro was a source of inspiration throughout. We thank members of the Howe lab for reviewing earlier versions of this manuscript. Joel Brown, Roberta Mason-Gamer, Christopher Whelan and Daniel Wenny provided helpful insights. We thank three anonymous reviewers for greatly improving this manuscript. Funding to P. Sethi was provided by Rufford Foundation, Wildlife Conservation Society; a Provost's award and University Fellowship from University of Illinois at Chicago.

\section{LITERATURE CITED}

ARA, H., MIA, M. M. \& KHAN, B. 2007. An annotated checklist of Lauraceae in Bangladesh. Bangladesh Journal of Plant Taxonomy 14:147-162.

BECKER, P. \& WONG, M. 1985. Seed dispersal, seed predation and juvenile mortality of Aglaia sp. (Meliaceae) in lowland dipterocarp rainforest. Biotropica 17:230-237.

CARlo, T. A., COLlAZO, J. A. \& GROOM, M. J. 2003. Avian fruit preferences across a Puerto Rican forested landscape: pattern consistency and implications for seed removal. Oecologia 134:119131.

CHAMPION, H. G. \& SETH, S. K. 1968. A revised survey of the forest types of India. Government of India Press, New Delhi. 404 pp.

CONNOLLY, J. D., LABBE, C., RYCROFT, D. S. \& TAYLOR, D. A. H. 1979. Tetranortriterpenoids and related compounds. Part 22. New apo-tirucallol derivatives and tetranortriterpenoids from the wood and seed of Chisocheton paniculatus (Meliaceae). Journal of the Chemical Society, Perkin Transactions 1:2959-2964.

CORLETT, R. T. 2007. The impact of hunting on the mammalian fauna of tropical Asian forests. Biotropica 39:292-303.

CRAMER, J., MESQUiTA, R. \& WILLIAMSON, G. B. 2007. Forest fragmentation differentially affects seed dispersal of large and small-seeded tropical trees. Biological Conservation 137:415423.

DATTA, A. 2001. An ecological study of sympatric hornbills and fruiting patterns in a tropical forest in Arunachal Pradesh. PhD Dissertation, Saurashtra University, Rajkot. 245 pp.

DATTA, A. \& RAWAT, G. S. 2003. Foraging patterns of sympatric hornbills during the nonbreeding season in Arunachal Pradesh, Northeast India. Biotropica 35:208-218.

ELANGOVAN, V., MARIMUTHU, G. \& KUNZ, T. H. 1999. Temporal patterns of individual and group foraging behaviour in the shortnosed fruit bat, Cynopterus sphinx, in South India. Journal of Tropical Ecology 15:681-687. 
FA, J. E., RYAN, S. F. \& BELL, D. J. 2005. Hunting vulnerability, ecological characteristics and harvest rates of bushmeat species in Afrotropical forests. Biological Conservation 121:167176.

FLEMING, T. H. 2005. The relationship between species richness of vertebrate mutualists and their food plants in tropical and subtropical communities differs among hemispheres. Oikos 11:556562.

GAUTIER-HION, A., DUPLANTIER, J. M., QURIS, R., FEER, F., SOURD, C., DECOUX, J. P., DUBOST, G., EMMONS, L., ERARD, C., HeCKeTSWEILER, P., MOUNGAZI, A., ROUSSILHON, C. \& THIOLLAY, J. M. 1985. Fruit characteristics as basis of fruit choice and seed dispersal in a tropical forest vertebrate community. Oecologia 65:324-337.

GRIMMETT, R., INSKIPP, C. \& INSKIPP, T. 2000. Pocket guide to the birds of the Indian subcontinent. Oxford University Press, New Delhi. $384 \mathrm{pp}$.

HAMANN, A. \& CURIO, E. 1999. Interactions among frugivores and fleshy fruit trees in a Philippine submontane rainforest. Conservation Biology 13:766-773.

HODGKISON, R., BALDING, S. T., ZUBAID, A. \& KUNZ, T. H. 2003. Fruit bats (Chiroptera: Pteropodidae) as seed dispersers and pollinators in a lowland Malaysian rain forest. Biotropica 35:491502.

HOLBROOK, K. M. \& LOISELLE, B. A. 2009. Dispersal in a Neotropical tree, Virolaflexuosa (Myristicaceae): does hunting of large vertebrates limit seed removal? Ecology 90:1449-1455.

HOWE, H. F. 1993. Specialized and generalized dispersal systems: where does the paradigm stand? Vegetatio 107/108:149-162.

HOWE, H. F. \& VANDE KERCKHOVE, G. A. 1980. Nutmeg dispersal by tropical birds. Science 210:925-927.

JORDANO, P. 1994. Spatial and temporal variation in the avianfrugivore assemblage of Prunus mahaleb: patterns and consequences. Oikos 71:479-491.

JORDANO, P. 1995a. Angiosperm fleshy fruits and seed dispersers: a comparative analysis of adaptation and constraints on plant-animal interactions. American Naturalist 145:163-191.

JORDANO, P. 1995b. Frugivore-mediated selection on fruit and seed size: birds and St. Lucie's cherry, Prunus mahaleb. Ecology 76:26272639.

JORDANO, P., GARCIA, C., GODOY, J. A. \& GARCIA-CASTAN, J. L. 2007. Differential contribution of frugivores to complex seed dispersal patterns. Proceedings of the National Academy of Sciences USA 104:3278-3282.

KiTAMuRA, S., YUMOTO, T., POONSWAD, P., CHUAIlUA, P., PLONGMAI, K., MARUHASHI, T. \& NOMA, N. 2002. Interactions between fleshy fruits and frugivores in a tropical seasonal forest in Thailand. Oecologia 134:559-572.

KITAMURA, S., SUZUKI, S., YUMOTO, T., POONSWAD, P., CHUAILUA, P., PLONGMAI, K., NOMA, N., MARUHASHI, T. \& SUCKASAM, C. 2004. Dispersal of Aglaia spectabilis, a large-seeded tree species in a moist evergreen forest in Thailand. Journal of Tropical Ecology 20:421427.
LEIGHTON, M. \& LEIGHTON, D. R. 1983. Vertebrate responses to fruiting seasonality within a Bornean rain forest. Pp. 191-196 in Sutton, S. L., Whitmore, T. C. \& Chadwick, A. C. (eds.). Tropical rain forest: ecology and management. Blackwell Scientific Publications, Oxford.

MANI, M. S. 1974. Ecology and biogeography in India. Dr. W. Junk, The Hague. 775 pp.

MCKEY, D. 1975. The ecology of coevolved seed dispersal systems. Pp. 159-191 in Gilbert, L. E. \& Raven, P. (eds.). Coevolution of animals and plants. University of Texas Press, Austin.

MENON, V. 2003. A field guide to Indian mammals. Penguin India, New Delhi. 200 pp.

MYERS, N., MITTERMEIER, R. A., MITTERMEIER, C. G., DA FONSECA, G. A. B. \& KENT, J. 2000. Biodiversity hotspots for conservation priorities. Nature 403:853-858.

NUNEZ-ITURRI, G., OLSSON, O. \& HOWE, H. F. 2008. Hunting reduces recruitment of primate-dispersed trees in Amazonian Peru. Biological Conservation 141:1536-1546.

PANNELL, C. M. \& KOZIOL, M. J. 1987. Ecological and phytochemical diversity of arillate seeds in Aglaia (Meliaceae): a study of vertebrate dispersal in tropical trees. Philosophical Transactions of the Royal Society of London. Series B, Biological Sciences 316:303333.

PRATT, T. K. \& STILES, E. W. 1985. The influence of fruit size and structure on composition of frugivores assemblages in New Guinea. Biotropica 17:314-321.

SAIKIA, B., KATAKY, J. C. S., MATHUR, R. K. \& BARUAH, J. N. 1978. New meliacins from the fruits of Chisocheton paniculatus Hiern. Indian Journal of Chemistry B16:1042-1044.

SCHUPP, E. W. 1993. Quantity, quality and the effectiveness of seed dispersal by animals. Vegetatio 107/108:15-29.

SCHUPP, E. W., JORDANO, P. \& GOMEZ, J. M. 2010. Seed dispersal effectiveness revisited: a conceptual review. New Phytologist 188:333-353.

SETHI, P. 2010. Seed dispersal and regeneration of hornbill-dispersed tree species in forests of the Indian Eastern Himalaya. Ph.D. dissertation. University of Illinois at Chicago, Chicago.

SETHI, P. \& HOWE, H. F. 2009. Recruitment of hornbill-dispersed trees in hunted and logged forests of the Indian Eastern Himalaya. Conservation Biology 23:710-718.

SOLANKI, G. S., KUMAR, A. \& SHARMA, B. K. 2008. Winter food selection and diet composition of capped langur (Trachypithecus pileatus) in Arunachal Pradesh, India. Tropical Ecology 49:157166.

VAN DER PIJL, L. 1982. Principles of dispersal in higher plants. (Second edition). Springer, Berlin. 215 pp.

VAZQUEZ, D. P., MORRIS, W. F. \& JORDANO, P. 2005. Interaction frequency as a surrogate for the total effect of animal mutualists on plants. Ecology Letters 8:1088-1094.

VELHO, N., DATTA, A. \& ISVARAN, K. 2009. Effect of rodents on seed fate of five hornbill-dispersed tree species in a tropical forest in north-east India. Journal of Tropical Ecology 25:507514. 
WENNY,D. G. \& LEVEY,D. J. 1998. Directed seed dispersal by bellbirds in a tropical cloud forest. Proceedings of the National Academy of Sciences USA 95:6204-6207.

WESTCOTT, D. A., BENTRUPPERBAUMER, J., BRADFORD, M. G. \& MCKEOWN, A. 2005. Incorporating patterns of disperser behaviour into models of seed dispersal and its effects on estimated dispersal curves. Oecologia 146:5767.

WHEELWRIGHT, N. T. 1985. Fruit size, gape width, and the diets of fruit-eating birds. Ecology 66:808-818.

WHITMORE, T. C. 1998. An introduction to tropical rain forests. (Second edition). Oxford University Press, Oxford. 296 pp.

Appendix 1. Visitation and seed removal by consumers of six tree species. The total per cent of seeds dispersed is calculated by (No. of visits $\times$ seeds dispersed per visit)/(Total seeds removed by all consumers $) \times 100$. Removed seeds include those that are swallowed/removed away from the focal tree and hence considered dispersed plus those that are dropped/predated under the tree). Similarly, the total per cent of seeds dropped refers to (No. of visits $\times$ seeds dropped per visit)/(Total seeds removed by all consumers) $\times$ 100. Ratufa bicolor, Callosciurus pygerythrus and Callosciurus erythraeus are seed predators which chewed capsules, seeds or carried seeds away to neighbouring crowns. In the case of Litsea monopetala, the data are shown both for four Litsea trees as well as three Litsea trees excluding the data for one tree which was located at the forest periphery and was visited by the rhesus macaque. The rhesus macaque is restricted to the forest periphery and is not found within the protected area and hence is not necessarily representative of seed dispersal within the protected area. Seed sizes for A. spectabilis and C. bejolghota are from Sethi (2010), for D. binectariferum, C. cumingianus and P. simiarum are from Sethi \& Howe (2009) and for L. monopetala are from Ara et al. (2007).

\begin{tabular}{|c|c|c|c|c|c|c|}
\hline Species & $\begin{array}{l}\text { Foraging visits } \\
\text { (N) }\end{array}$ & $\begin{array}{c}\text { Mean visit } \\
\text { duration (min) }\end{array}$ & $\begin{array}{c}\text { Mean no. of } \\
\text { seeds dispersed } \\
\text { per visit }\end{array}$ & $\begin{array}{c}\text { Mean no. of } \\
\text { seeds dropped } \\
\text { per visit }\end{array}$ & $\begin{array}{c}\text { Total \% of } \\
\text { seeds dispersed }\end{array}$ & $\begin{array}{c}\text { Total \% of } \\
\text { seeds dropped }\end{array}$ \\
\hline \multicolumn{7}{|c|}{ 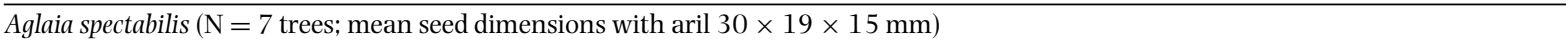 } \\
\hline \multicolumn{7}{|c|}{ Birds } \\
\hline Buceros bicornis & 5 & 22 & 8.8 & 0.3 & 30.4 & 0.7 \\
\hline Rhyticeros undulatus & 19 & 4 & 3.8 & 0.8 & 50 & 11 \\
\hline Anthracoceros albirostris & 6 & 13 & 1.7 & 0 & 6.9 & 0 \\
\hline Ducula badia & 1 & 5 & 1 & 0 & 0.7 & 0 \\
\hline \multicolumn{7}{|l|}{ Mammals } \\
\hline Ratufa bicolor & 1 & 15 & 0 & 1 & 0 & 0.7 \\
\hline Callosciurus pygerythrus & 1 & 10 & 0 & 0 & 0 & 0 \\
\hline \multicolumn{7}{|c|}{ Chisocheton cumingianus $(\mathrm{N}=9$ trees; mean seed dimensions with aril $31 \times 24 \times 19 \mathrm{~mm})$} \\
\hline \multicolumn{7}{|c|}{ Birds } \\
\hline Buceros bicornis & 2 & 5 & 3.5 & 0 & 6 & 0 \\
\hline Rhyticeros undulatus & 1 & 8 & 0 & 3 & 0 & 2.6 \\
\hline Anthracoceros albirostris & 22 & 9 & 1.4 & 0.6 & 25.6 & 11.1 \\
\hline \multicolumn{7}{|l|}{ Mammals } \\
\hline Callosciurus pygerythrus & 4 & 17 & 0 & 0.5 & 0 & 1.7 \\
\hline Callosciurus erythraeus & 5 & 15 & 0 & 12.3 & 0 & 53 \\
\hline \multicolumn{7}{|c|}{ Dysoxylum binectariferum ( $\mathrm{N}=12$ trees, 3 in 2005 and 9 in 2006; mean seed dimensions with aril $30 \times 22 \times 17 \mathrm{~mm}$ ) } \\
\hline \multicolumn{7}{|c|}{ Birds } \\
\hline Buceros bicornis & 36 & 5.7 & 2.9 & 0.6 & 35.7 & 7.3 \\
\hline Rhyticeros undulatus & 13 & 8.5 & 3.2 & 0.7 & 14.3 & 3.1 \\
\hline Anthracoceros albirostris & 31 & 6.5 & 1.9 & 0.1 & 16.4 & 1.0 \\
\hline Ducula badia & 49 & 11.2 & 0.7 & 0.07 & 7.7 & 0.7 \\
\hline \multicolumn{7}{|l|}{ Mammals } \\
\hline Ratufa bicolor & 1 & 1 & 0 & 0 & 0 & 0 \\
\hline Callosciurus pygerythrus & 6 & 5.3 & 0.7 & 2.3 & 1.4 & 4.9 \\
\hline Callosciurus erythraeus & 7 & 12 & 1.3 & 1.7 & 3.1 & 4.2 \\
\hline \multicolumn{7}{|c|}{ Polyalthia simiarum $(\mathrm{N}=9$ trees; mean seed dimensions $29 \times 20 \times 17 \mathrm{~mm})$} \\
\hline \multicolumn{7}{|l|}{ Birds } \\
\hline Buceros bicornis & 11 & 5 & 7.9 & 4.6 & 6.3 & 3.7 \\
\hline Rhyticeros undulatus & 3 & 4 & 7.3 & 0.7 & 1.6 & 0.2 \\
\hline Anthracoceros albirostris & 5 & 8 & 7.8 & 1 & 2.8 & 0.4 \\
\hline Ducula badia & 1 & 2 & 1 & 0 & 0.1 & 0 \\
\hline Gracula religiosa & 2 & 12 & 0 & 2 & 0 & 0.3 \\
\hline \multicolumn{7}{|l|}{ Mammals } \\
\hline Ratufa bicolor & 3 & 21 & 0 & 24.7 & 0 & 5.4 \\
\hline Callosciurus pygerythrus & 1 & & 0 & 12 & 0 & 0.9 \\
\hline Callosciurus erythraeus & 6 & 10 & 0 & 9.5 & 0 & 4.2 \\
\hline Macaca mulatta & 14 & 24 & 33.4 & 39.3 & 34.1 & 40.1 \\
\hline
\end{tabular}


Appendix 1. Continued

\begin{tabular}{|c|c|c|c|c|c|c|}
\hline Species & $\begin{array}{l}\text { Foraging visits } \\
\text { (N) }\end{array}$ & $\begin{array}{c}\text { Mean visit } \\
\text { duration (min) }\end{array}$ & $\begin{array}{l}\text { Mean no. of } \\
\text { seeds dispersed } \\
\text { per visit }\end{array}$ & $\begin{array}{c}\text { Mean no. of } \\
\text { seeds dropped } \\
\text { per visit }\end{array}$ & $\begin{array}{c}\text { Total } \% \text { of } \\
\text { seeds dispersed }\end{array}$ & $\begin{array}{c}\text { Total \% of } \\
\text { seeds dropped }\end{array}$ \\
\hline \multicolumn{7}{|c|}{ Litsea monopetala $-(\mathrm{N}=4$ trees; $7-12 \times 5 \times 5 \mathrm{~mm})$} \\
\hline \multicolumn{7}{|c|}{ Birds } \\
\hline Buceros bicornis & 2 & 2 & 3 & 0 & 0.2 & 0 \\
\hline Anthracoceros albirostris & 16 & 15 & 74.1 & 2.4 & 29.1 & 1 \\
\hline Ducula badia & 24 & 8 & 12.9 & 0.5 & 7.6 & 0.3 \\
\hline Mulleripicus pulverulentus & 1 & 2 & 0 & 0 & 0 & 0 \\
\hline Picus flavinucha & 10 & 3 & 4 & 0.2 & 1 & 0.03 \\
\hline Picus canus & 1 & 5 & 0 & 0 & 0 & 0 \\
\hline Chrysocolaptes lucidus & 4 & 4 & 0 & 0 & 0 & 0 \\
\hline Megalaima lineata & 5 & 4 & 2.5 & 0 & 0.3 & 0 \\
\hline Megalaima asiatica & 2 & 3 & 10 & 0 & 0.5 & 0 \\
\hline Irena puella & 69 & 2 & 5.9 & 0.4 & 10 & 0.6 \\
\hline Acridotheres tristis & 4 & 2 & 4 & 1 & 0.4 & 0.1 \\
\hline Acridotheres fuscus & 1 & 4 & 8 & 1 & 0.2 & 0.03 \\
\hline Gracula religiosa & 37 & 6 & 10.7 & 0.6 & 9.7 & 0.6 \\
\hline Pycnonotus melanicterus & 45 & 3 & 2.3 & 0 & 2.5 & 0 \\
\hline Pycnonotus jocosus & 34 & 1 & 2.6 & 0.3 & 2.14 & 0.3 \\
\hline Pycnonotus cafer & 14 & 2 & 1.8 & 0.1 & 0.6 & 0.1 \\
\hline Alophoixus flaveolus & 25 & 1 & 2 & 0.05 & 1.2 & 0.03 \\
\hline Hemixos flavala & 4 & 1 & 1.7 & 0 & 0.2 & 0 \\
\hline Hypsipetes leucocephalus & 5 & 3 & 3 & 0 & 0.4 & 0 \\
\hline Garrulax monileger & 3 & 6 & 1 & 0 & 0.1 & 0 \\
\hline \multicolumn{7}{|l|}{ Mammals } \\
\hline Callosciurus pygerythrus & 5 & 6 & 0.8 & 7 & 0.1 & 0.9 \\
\hline Macaca mulatta & 3 & 68 & 3 & 406.5 & 30 & 0.2 \\
\hline \multicolumn{7}{|c|}{ Litsea monopetala $-(\mathrm{N}=3$ trees, seed dimensions as above $)$} \\
\hline \multicolumn{7}{|c|}{ Birds } \\
\hline Buceros bicornis & 2 & 2 & 3 & 0 & 0.3 & 0 \\
\hline Anthracoceros albirostris & 15 & 15 & 79.8 & 2.6 & 52 & 1.7 \\
\hline Ducula badia & 19 & 8 & 13.3 & 0.3 & 11 & 0.3 \\
\hline Mulleripicus pulverulentus & 1 & 2 & 0 & 0 & 0 & 0 \\
\hline Picus flavinucha & 5 & 3 & 3.3 & 0.3 & 0.7 & 0.1 \\
\hline Picus canus & 1 & 5 & 0 & 0 & 0 & 0 \\
\hline Chrysocolaptes lucidus & 2 & 4 & 0 & 0 & 0 & 0 \\
\hline Megalaima lineata & 4 & 4 & 3 & 0 & 0.5 & 0 \\
\hline Megalaima asiatica & 0 & 3 & - & - & - & - \\
\hline Irena puella & 60 & 2 & 5.8 & 0.4 & 15.2 & 1 \\
\hline Acridotheres tristis & 0 & 2 & 0 & 0 & 0 & 0 \\
\hline Acridotheres fuscus & 0 & 4 & - & - & - & - \\
\hline Gracula religiosa & 18 & 6 & 7.5 & 0.2 & 5.9 & 0.2 \\
\hline Pycnonotus melanicterus & 37 & 3 & 2.1 & 0 & 3.3 & 0 \\
\hline Pycnonotus jocosus & 32 & 1 & 2.5 & 0.3 & 3.5 & 0.4 \\
\hline Pycnonotus cafer & 11 & 2 & 1.5 & 0 & 0.7 & 0 \\
\hline Alophoixus flaveolus & 21 & 1 & 2.1 & 0.06 & 1.9 & 0.04 \\
\hline Hemixos flavala & 4 & 1 & 1.7 & 0 & 0.3 & 0 \\
\hline Hypsipetes leucocephalus & 5 & 3 & 3 & 0 & 0.7 & 0 \\
\hline Garrulax monileger & 3 & 6 & 0 & 1 & 0.1 & 0 \\
\hline \multicolumn{7}{|l|}{ Mammals } \\
\hline Callosciurus pygerythrus & 2 & 6 & 0 & 4.5 & 0 & 0.4 \\
\hline Macaca mulatta & 0 & 68 & - & - & - & - \\
\hline \multicolumn{7}{|c|}{ Cinnamomum bejolghota $(\mathrm{N}=2$ trees in 2005 and 6 in 2006; mean seed dimensions $11 \times 7 \times 6 \mathrm{~mm})$} \\
\hline \multicolumn{7}{|c|}{ Birds } \\
\hline Buceros bicornis & 4 & 4.8 & 3.8 & 0 & 1.8 & 0 \\
\hline Rhyticeros undulatus & 4 & 5.5 & 6.8 & 0 & 3.2 & 0 \\
\hline Anthracoceros albirostris & 1 & 5 & 2 & 0 & 0.2 & 0 \\
\hline Picus flavinucha & 19 & 3.3 & 2.9 & 0.3 & 4.7 & 0.5 \\
\hline Picus chlorolophus & 3 & 1.3 & 0 & 0 & 0 & 0 \\
\hline Megalaima virens & 13 & 4.1 & 5.8 & 0.1 & 6.2 & 0.1 \\
\hline Megalaima lineata & 12 & 4 & 9.1 & 08 & 8.6 & 0.7 \\
\hline Megalaima asiatica & 61 & 2.6 & 2.6 & 0.3 & 17.3 & 2.3 \\
\hline
\end{tabular}


Appendix 1. Continued

\begin{tabular}{|c|c|c|c|c|c|c|}
\hline Species & $\begin{array}{l}\text { Foraging visits } \\
\text { (N) }\end{array}$ & $\begin{array}{c}\text { Mean visit } \\
\text { duration (min) }\end{array}$ & $\begin{array}{l}\text { Mean no. of } \\
\text { seeds dispersed } \\
\text { per visit }\end{array}$ & $\begin{array}{l}\text { Mean no. of } \\
\text { seeds dropped } \\
\text { per visit }\end{array}$ & $\begin{array}{c}\text { Total \% of } \\
\text { seeds dispersed }\end{array}$ & $\begin{array}{c}\text { Total \% of } \\
\text { seeds dropped }\end{array}$ \\
\hline Irena puella & 31 & 2.4 & 1.7 & 0.2 & 5.1 & 0.6 \\
\hline Chloropsis aurifrons & 2 & 2 & 0 & 0 & 0 & 0 \\
\hline Myophonus caeruleus & 1 & 3 & 0 & 0 & 0 & 0 \\
\hline Gracula religiosa & 40 & 2.9 & 4.6 & 1.3 & 12.1 & 3.3 \\
\hline Pycnonotus melanicterus & 68 & 2 & 1.3 & 0.2 & 6.5 & 1.2 \\
\hline Alophoixus flaveolus & 82 & 1.1 & 0.9 & 0.1 & 5.6 & 0.4 \\
\hline Hemixos flavala & 3 & 0.3 & 1 & 0 & 0.1 & 0 \\
\hline Hypsipetes leucocephalus & 49 & 0.9 & 1.1 & 0 & 3.6 & 0 \\
\hline Arachnothera magna & 2 & 2.5 & 6 & 0 & 0.7 & 0 \\
\hline \multicolumn{7}{|l|}{ Mammals } \\
\hline Ratufa bicolor & 2 & 28.5 & 0 & 24 & 0 & 5.7 \\
\hline Callosciurus pygerythrus & 6 & 0 & 1.7 & 1.3 & 1.2 & 0.9 \\
\hline Callosciurus erythraeus & 14 & 35.4 & 0 & 3.9 & 0 & 5.6 \\
\hline Trachypithecus pileatus & 7 & 7.4 & 13 & 0 & 1.5 & 0 \\
\hline
\end{tabular}

